\title{
CONSERVATION PRACTICE AND THE FUTURE OF DOCTRINAL TEXTS
}

\section{WALTER Nigel ${ }^{1}$}

${ }^{1}$ Nigel Walter, Department of Archaeology, University of York https://orcid.org/0000-0002-1152-522X

ABSTRACT: 2021 marks the 90th anniversary of the adoption of the Athens Charter. This, the first international conservation charter, now forms part of the rapidly expanding collection of 'doctrinal texts' which undergirds modern conservation. Whatever its strengths and weaknesses, this collection provides a marker of collective identity and is crucial to the selfdefinition of our discipline.

While they are rightly held in great affection, this paper argues that to approach this collection of texts uncritically risks producing unintended consequences, potentially including the destruction of important heritage. Precisely because of their enduring influence, it is essential that as a discipline conservation engages in knowledgeable criticism of its doctrinal texts, through an appropriate and hermeneutically literate reading.

This paper first considers the nature of doctrinal texts, before using the notion of 'doctrine' to explore some of the parallels and differences between doctrinal texts of a religious nature and those of conservation, and so to introduce the question of hermeneutics. This then leads to a discussion of the relation between theory and practice, and the notion, from Aristotle, of phronesis or practical wisdom. The paper then concludes with consideration of some of the implications conservation of adopting this approach.

KEY WORDS: doctrinal text, hermeneutics, historic buildings, phronesis, Prudentia, HansGeorg Gadamer 
2021 marks the 90th anniversary of the adoption of the Athens Charter. This, the first international conservation charter, now forms part of the rapidly expanding collection of 'doctrinal texts' which undergirds modern conservation. Whatever its strengths and weaknesses, this collection provides a marker of collective identity and is crucial to the self-definition of our discipline.

While this collection of texts is rightly held in great affection, this paper argues that to approach them uncritically risks producing unintended consequences, potentially including the destruction of important heritage. Precisely because of their enduring influence, it is essential that as a discipline conservation engages in knowledgeable criticism of its doctrinal texts, not merely at the time of their composition, but on a continuous and ongoing basis. This is true both at a text-by-text level, but also at the overarching level, where the potential implications are just as great but a critical appraisal is less apparent. Indeed there are questions as to what these texts collectively add up to: do they display the organisational structure and intentionality that merits describing them as a 'corpus', or should we treat them instead as something altogether looser and less formal?

The Athens Charter begins with seven resolutions, collectively known as the 'Carta del Restauro'. Of these, the second states that 'Proposed Restoration projects are to be subjected to knowledgeable criticism to prevent mistakes which will cause loss of character and historical values to the structures'. What the charter says of Restoration projects - and here we can in current terminology surely add 'Conservation projects' - I suggest can be applied metaphorically to refer to these doctrinal texts which give identity and definition to our discipline. It is in this second resolution that the potential danger implicit in the production of doctrinal texts is hinted at - the possibility that they themselves may in time, and/or in specific places, become positively harmful, causing 'loss of character and historical values' to the very structures conservation seeks to protect.

This paper first considers the nature of doctrinal texts, before using the notion of 'doctrine' to explore the parallels and differences between doctrinal texts of a religious nature and those of conservation, and so to introduce the question of hermeneutics. This then leads to a discussion of the relation between theory and practice, and the notion, from Aristotle, of phronesis or practical wisdom. The paper then concludes with consideration of some implications of this approach.

\section{Doctrinal Texts}

Doctrinal texts are clearly important - they are seen as the primary means of formulating a structured body of conservation theory, and thus creating a legible framework for the care and management of heritage. One advantage of such texts is that they are typically international in authorship and character; even those that originate with national committees often escape those confines and become applied more broadly, as with the Burra Charter ${ }^{1}$ (at times not

${ }^{1}$ The Burra Charter: The Australia ICOMOS Charter for Places of Cultural Significance, Burwood, Australia: Australia ICOMOS, 2013. 
uncontroversially), and perhaps to a lesser degree with documents such as the ICOMOS-UK Cultural Heritage Manifesto' ${ }^{2}$. And then of course there are older 'classics' that deserve a place in our collection such as the Manifesto for the Society for the Protection of Ancient Buildings $(\mathrm{SPAB})^{3}$, which some would rank as the first in this still growing line of doctrinal texts.

Applying the adjective 'doctrinal' to any text brings with it a series of associations. In common use, a doctrine is a belief, or set of beliefs, that are held - and usually also advanced - by a group; doctrine therefore has both a communal dimension, being more than of merely personal concern, and is also outward facing. The word is derived from the Latin docere, to teach (which also gives us the earlier sense of a 'doctor' as a teacher). This active aspect of teaching is even more evident in doctrine's Greek cognate catechesis, which retains more of an explicitly religious connotation. While there are also legal and political uses of the word 'doctrine', the religious connotation is persistent and cannot be ignored.

Conservation has for several decades now referred to its growing infrastructure of charters, guidance and other documents as 'doctrinal texts'. In November 1984, the 33rd session of the ICOMOS Executive Committee approved its 'Procedure For The Adoption Of A Doctrinal Text' which, alongside the outline of an adoption process, includes the following definition: 'A doctrinal text is a group of ideas which one affirms to be true and by which one claims to furnish an interpretation of facts in order to direct action'.

There are three important elements to draw from this helpful definition. First, doctrinal texts make truth claims; we should not be surprised if, in an age of postmodern relativism, such affirmation is increasingly viewed with suspicion, just as the doctrinal claims of organised religion are now viewed more sceptically than in previous ages. Second, doctrinal texts are interpretative in their intent. That is to say they provide tools or a framework to guide us in our work; this paper extends this to argue that they are themselves 'facts' in need of interpretation. And third, doctrinal texts are directed towards action in the world; their purpose is to inform and guide the decision making of conservation professionals, which means they directly influence real-world outcomes. This sense of agency gives them their power, with which comes responsibility; hence the pressing need for critical engagement.

These three elements - affirmation, interpretation and action - are the core of this definition, but it should be noted how readily it can also be applied to explicitly religious texts. This paper takes the strength of that parallel and reverses it, asking what light the way religious doctrinal texts are approached might shed on our investigation of the doctrinal texts of conservation.

\footnotetext{
${ }^{2}$ A Cultural Heritage Manifesto, ICOMOS-UK, 2015, http://www.icomos-uk.org/uploads/sidebar/ PDF/A\%20Cultural\%20Heritage\%20Manifesto.pdf.

${ }^{3}$ Morris W., The Society for the Protection of Ancient Buildings Manifesto, [1877] 2018, https:/www. spab.org.uk/about-us/spab-manifesto.
} 


\section{Structuring the 'Collection'}

First we should consider how, if at all, this family of doctrinal texts is structured. At the Conference of the ICOMOS International Scientific Committee for the Theory and the Philosophy of Conservation and Restoration (Theophilos) in Vienna in April 2008, Bogusław Szmygin offered an initial analysis of doctrinal texts, proposing a fourfold taxonomic framework of 'charters', 'guidelines', 'principles' and more general 'documents', each with their distinct scope, form of adoption, area of concern, level of durability, etc. ${ }^{4}$ These four categories were then ranked in a hierarchy of importance from charters at the top through principles and guidance to documents at the bottom, all with a view to prompting the development of a recognisable structure for the ordering of existing and particularly future texts.

This taxonomy was adopted as the basis of a 2008 resolution of the ICOMOS General Assembly which called for the creation of 'draft criteria for guiding the production of future Doctrinal Texts for ICOMOS 5 . In turn, this led in 2009 to the development with Theophilos and the ICOMOS International Scientific Committee on Legal, Administrative and Financial Issues (ICLAFI) of nine proposals for doctrinal texts, which were presented to the ICOMOS Advisory Committee $^{6}$ in 2009. This resulted in 2010 in the adoption of a set of criteria for doctrinal texts by the ICOMOS Executive Committee.

However, Szmygin also observed that the arbitrariness and incoherence of the production of the doctrinal texts that make up this framework means that these texts fail in their most basic function of providing a normative structure for the discipline. Indeed, as he suggests, the current free-for-all nature of the way texts are produced means that almost any intervention can be justified with reference to some text or other; and that the growing number of texts is part of the problem: 'The existence of too many documents leads to devaluation of their contents, weakens their position or undermines their sense altogether'.

In an attempt to ensure commensurability, many doctrinal texts strive to maintain consistency with other documents within the collection. The most obvious signaling of this ambition is to commence one's text with reference to other existing texts. For example, the preamble to the

${ }^{4}$ Szmygin B., Formal Analysis of Doctrinal Texts in Heritage Protection, [in:] M. S. Falser, W. Lipp, A. Tomaszewski (eds.) Conservation and Preservation: Interactions between Theory and Practice: In Memoriam Alois Riegl (1858-1905). Firenze: Edizioni Polistampa, 2010, pp. 97-106.

${ }^{5}$ Resolutions of the 16th General Assembly, Paris: ICOMOS, 2008, resolution 24, p. 11, https://www. icomos.org/quebec2008/resolutions/pdf/GA16_Resolutions_final_EN.pdf.

${ }^{6}$ Annual Report 2009, Volume 1, Paris: ICOMOS, 2013, https://www.icomos.org/images/ DOCUMENTS/Secretariat/Annual_Reports/AR2009_Vol1complet_finalweb_20130618.pdf.

7 Szmygin B., Formal Analysis of Doctrinal Texts in Heritage Protection, [in:] M. S. Falser, W. Lipp, A. Tomaszewski (eds.) Conservation and Preservation: Interactions between Theory and Practice: In Memoriam Alois Riegl (1858-1905). Firenze: Edizioni Polistampa, 2010, p. 98. 
Venice Charter ${ }^{8}$ locates it in a direct line of descent from the Athens Charter. In turn, the Nara Document on Authenticity declares that it was 'conceived in the spirit of the Charter of Venice, 1963, and builds on it and extends it in response to the expanding scope of cultural heritage concerns and interests in our contemporary world'. However sincerely such declarations are made, of themselves they offer no guarantee of compatibility, as many would argue is clear from comparing the content of those last two texts.

In response to this concern for commensurability we should perhaps question the extent to which this collection of documents can ever achieve any significant level of coherence. While the official adoption by ICOMOS of a taxonomy was an important step forward, it does nothing to excuse us from the work of developing an appropriate hermeneutic for the interpretation both of individual texts and of the entire collection. Indeed, as Szmygin noted, the greater the number of texts, the greater the potential for inter-textual contradiction, and thus the greater the need for that work of interpretation. And in developing that interpretative framework, cultural context is key, just as much when placing a text within its context as when placing a building within its setting.

One clear example - from outside of ICOMOS - where sincere efforts to assert compatibility are contradicted by the substance of the relevant texts is the Convention for the Safeguarding of the Intangible Cultural Heritage (CSICH $)^{10}$. Article 3 of the $\mathrm{CSICH}$ is careful to stipulate that where an item of the intangible cultural heritage is directly associated with a property protected by the 1972 World Heritage Convention ${ }^{11}$, that protection is not altered or diminished. The stated ambition is clearly that the two forms of heritage will coexist unproblematically, but this ignores the reality that the two regimes do not enjoy a clean demarcation of sovereignty, indeed that the two 'realms' substantially overlap, and that notions of significance, for example, will inevitably be contested.

A second strategy when contemplating inconsistencies between texts is to propose the updating of older texts to conform to current norms. We could, for example, consider amending the Venice Charter to acknowledge the important role of non-expert stakeholders. But however justified such a change might be, the Venice Charter is not ours to update! It was the product of its time and place and, after almost 60 years, is surely best left in peace; to change it now would be to dishonour those who drafted it and would itself be historically illiterate.

${ }^{8}$ International Charter on the Conservation and Restoration of Monuments and Sites, Paris: ICOMOS, 1964.

9 The Nara Document on Authenticity, ICOMOS, 1994, p. 3, https://www.icomos.org/charters/nara-e. pdf.

${ }^{10}$ Convention for the Safeguarding of the Intangible Cultural Heritage, UNESCO 2002, https://ich. unesco.org/en/convention; Walter N., Narrative Theory in Conservation: Change and Living Buildings, Abingdon and New York: Routledge, 2020, pp. 84-85.

${ }^{11}$ Convention Concerning the Protection of the World Cultural and Natural Heritage, UNESCO 1972, http://whc.unesco.org/archive/convention-en.pdf. 
On the other hand, this recognisable urge to update is useful in alerting us to an important underlying belief, namely the presumption, and thence the ambition, that these doctrinal texts should form a coherent corpus. I would suggest, however, the inconsistencies that undoubtedly exist are better seen as serving a useful purpose in calling into question this ambition for this tidy coherence. For any individual text it is far better to place it into its context and embrace the necessary work of interpretation, than to chase the fantasy of ultimate commensurability.

\section{Sacredness}

But I would go further and suggest that this search for coherence in the face of contradiction is an indication that these texts have become elevated to the status of the sacred. From the early days of modern conservation, there have been close parallels observable between historic buildings, historic landscapes and historic and sacred texts. For example, Stephen Daniels and Denis Cosgrove ${ }^{12}$ observe John Ruskin's focus on landscape as central to a social, political and environmental morality, and his treatment of it as a text, on the model of biblical exegesis. Or take the heroic opening words to the preamble to the Venice Charter - 'Imbued with a message from the past...' which resonate with a sense of the sacred.

With this, and the overlapping definition discussed above, it is perhaps unsurprising that the doctrinal texts of conservation might take on some of the characteristics of religious texts. There are multiple parallels. First, like both the Hebrew and Christian Bibles, the texts of conservation are collections of separate works, spanning a range of genres and written by multiple authors. Second, these individual texts were composed over time, and understanding that historical relation and the interweaving of texts through cross reference is essential to their interpretation, particularly in light of their (at least apparent) intra- and inter-textual contradictions.

And then third, there is the question of canonicity, the process by which some texts are chosen for inclusion within 'the canon', and others excluded, albeit with the recognition that those that are excluded may well still reward close scrutiny. In the one case, the development of the Christian canon was entrusted to a series of regional councils at Laodicea, Carthage, etc; these did not select works to include in the canon, but rather recognised those texts that were already acknowledged as canonical in the practice of those regional churches. In the other case, the development of individual texts within the conservation canon has been entrusted to a series of councils - national, regional and international - most obviously under the auspices of ICOMOS. One obvious difference is that while the canon of Christian Scripture has been settled for sixteen centuries, the canon of conservation texts is both still hotly debated, and indeed constantly added to.

${ }^{12}$ Daniels S., Cosgrove D. E., Introduction: Iconography and Landscape, [in:] The Iconography of Landscape : Essays on the Symbolic Representation, Design, and Use of Past Environments, Cambridge and New York: Cambridge University Press, 1988, pp. 1-10. 
Alongside these parallels and differences between the two types of doctrinal texts, comes a common need for a thorough hermeneutic approach to their interpretation. Some texts may still be valued while not being adhered to as their creators intended. To take one small example, Conclusion VI of the Athens Charter on The Technique of Conservation recommends that

...In the case of ruins, scrupulous conservation is necessary, and steps should be taken to reinstate any original fragments that may be recovered (anastylosis), whenever this is possible; the new materials used for this purpose should in all cases be recognisable.

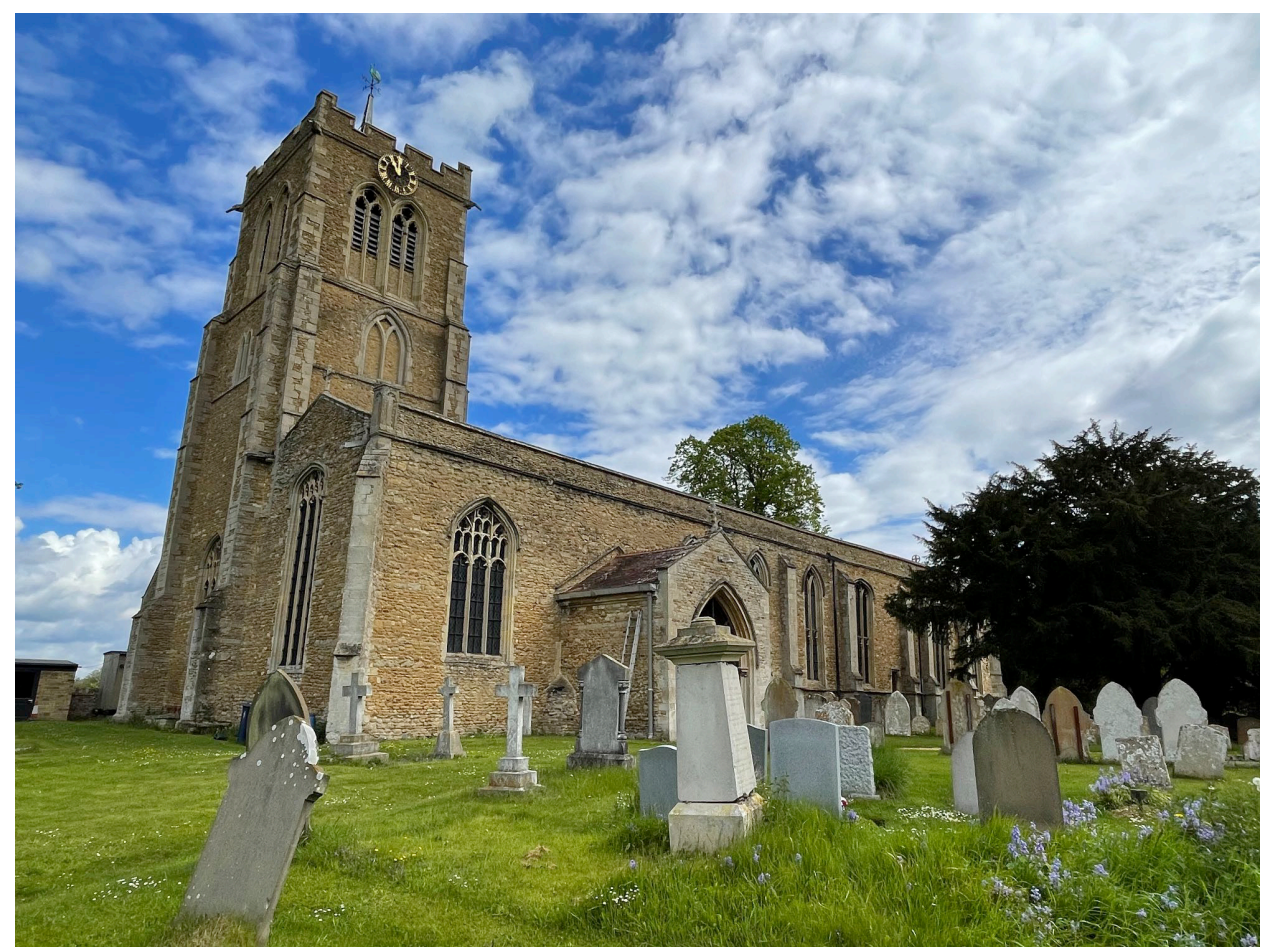

Fig. 1 The Parish Church of St Andrew, Swavesey

And indeed, the Venice Charter repeats a similar provision under article 15 (excavations). Close inspection of the grade I listed medieval church of St Andrew, Swavesey near Cambridge (Fig. 1) shows an instance of this recommendation in action. One of the mullions of the belfry openings on the east face of the tower includes a relatively minor repair (Fig. 2): where a section of stonework has failed, the mullion has been made good using tilework to ensure the repair is historically legible, very much in the spirit the Athens recommendation and known in the UK as a 'SPAB repair'. However, this would not be the approach that would generally be adopted now; instead, current practice would be to replace failed stonework with stone to match, in performance, in appearance, and if at all possible from the same quarry. The 'SPAB repair' has gone from international orthodoxy to becoming a comment on a historically distinct philosophy of repair, and arguably thereby gaining heritage interest in its own right, declaring that 'we used to do it this way, but not any more'. 
104 Nigel Walter

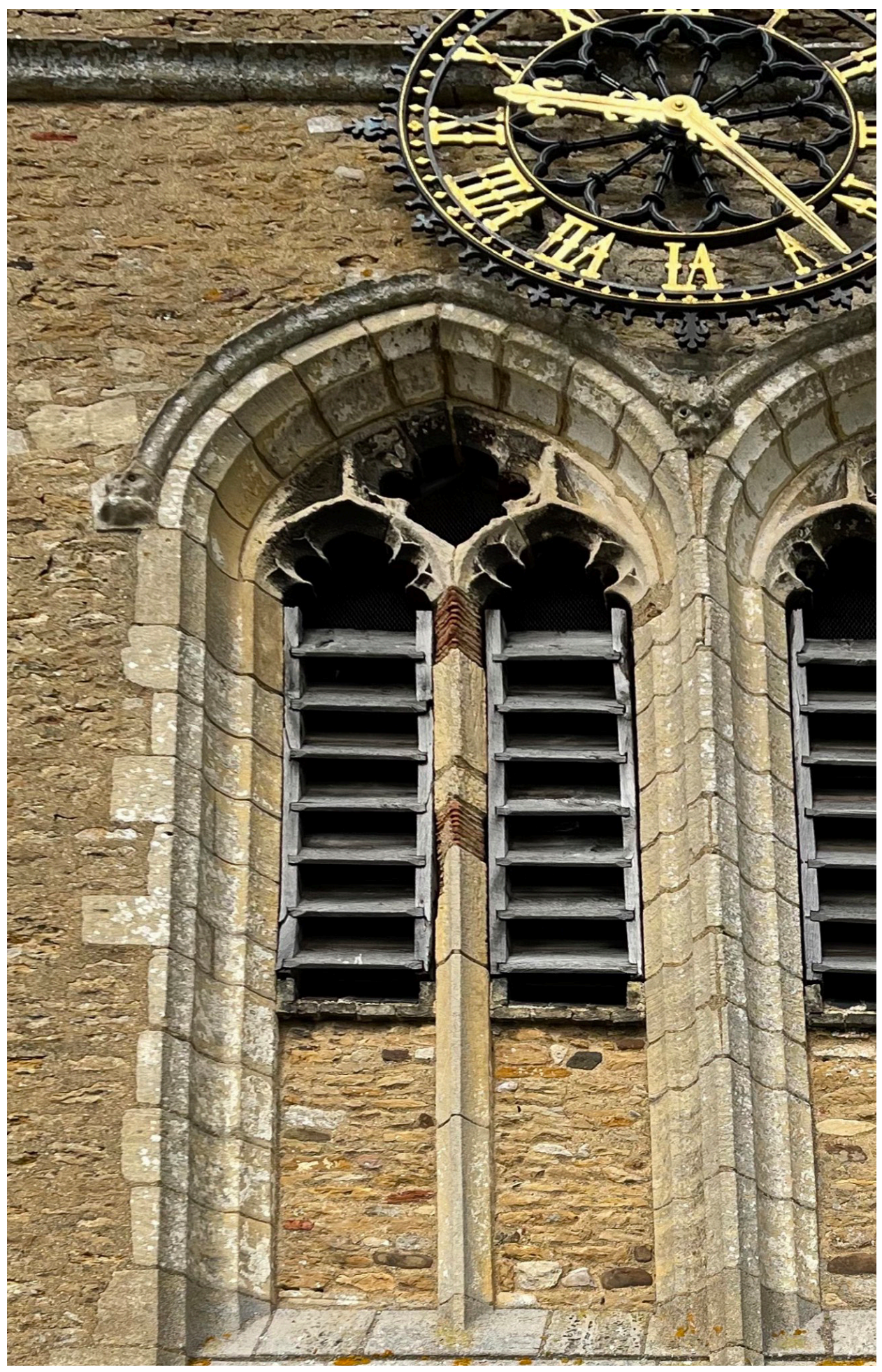

Fig. 2: The Parish Church of St Andrew, Swavesey - East Belfry Stonework 


\section{Hermeneutics}

To interpret that section of the Athens Charter requires us to read the text at more than face value; it requires us to engage with hermeneutics, the art of interpretation. Developed from philology, it was originally concerned with the translation of classical and scriptural texts, before then being progressively broadened by Friedrich Schleiermacher, Wilhelm Dilthey, Martin Heidegger and Hans-Georg Gadamer ${ }^{13}$ to become universalised in scope so that, for Gadamer, hermeneutics provides the foundation for all forms of human understanding. Gadamer's achievement, notably in his Truth and Method ${ }^{14}$, was to articulate this universality of hermeneutics: that it is a condition of being human, rather than merely a methodological adjunct to another area of study. He describes hermeneutics as 'the universal linguisticality of man's relation to the world' ${ }^{15}$.

Any 'text', broadly understood - and in this, following Gadamer's approach to hermeneutics, we must include buildings such as those which are of concern to conservation - requires interpretation. No cultural artefact can be understood in isolation without reference to its context. While the importance of physical context to historic buildings has long been recognised in conservation, at least at the level of theory (Article 6 of the Venice Charter, Resolution 7 of the Athens Charter), the same is less true of temporal context. Without that temporal context, both historic buildings and doctrinal texts are typically treated as artefacts now decisively separated from the historic flow from whence they came.

Culture is not static, but rather dynamic; nothing cultural stands still for long, not even something as seemingly concrete as a building, or indeed a doctrinal text. We witness this at the level of individual words. David Lowenthal uses the starkly comic example of the Isaac Watts hymn 'How blest the man whose bowels move'16, to show how meanings change - in this specific case that, since the eighteenth century, the seat of our emotions has migrated from the stomach to the heart. Not only are words unstable in this way, 'dancing' before us, they also rarely enjoy the luxury of a single meaning, but more typically refer to a richer zone of reference. This is evident when faced with the familiar challenges of translating a text from one language into another, the more so the more condensed, poetic and allusive the language.

However, this need for interpretation does not mean that words, or indeed whole texts/buildings, can be made to mean whatever we wish. They have an existence independent of the 'reader', and indeed we should expect - and therefore leave space for - a doctrinal text or historic building to challenge us as we engage with it. But that does not make the meaning of the text static.

${ }^{13}$ Grondin J., Introduction to Philosophical Hermeneutics, New Haven, CT: Yale University Press, 1994, pp. 1-15.

${ }^{14}$ Gadamer H.-G., Truth and Method, (J. Weinsheimer \& D. G. Marshall, trans.). 2nd, rev. ed. London: Sheed and Ward, [1960] 1989.

${ }^{15}$ Gadamer H.-G., On the Scope and Function of Hermeneutical Reflection, (D. E. Linge, trans.), [in:] Philosophical Hermeneutics, Berkeley and Los Angeles, CA: University of California Press, 1976, p. 19.. ${ }^{16}$ Lowenthal D., The Past Is a Foreign Country - Revisited, Cambridge: Cambridge University Press, 2015, p. 546. 
Texts do not exist in isolation; even when the letter of the other texts with which they interlock remains unchanged, they still refer to a cultural context, to a situation, that is anything but fixed. This context illuminates them or, conversely, comes to hide them, potentially rendering them inaccessible, as with the Watts example just mentioned.

All of this points to the essential role that interpretation plays in our understanding. When considering the relationship between a given text and our experience of the world - and the possible claims of one upon the other - we can describe what could be called a 'hermeneutic spectrum'. At one end of this spectrum stands 'literalism', under which the text is given priority over experience; at the other end stands 'liberalism, which reverses that priority, placing our experience over the text. At the one extreme the text subsumes all else, such that the reader becomes deaf to lived experience; at the other, the text is conformed to the world, such that the text loses all distinctiveness and no longer has anything useful to say. In a religious context, the first position results in fundamentalism, while the second leads to absorption by and disappearance into the culture. At neither extreme is there scope for Gadamer's 'fusion of horizons ${ }^{17}$ that is essential to all understanding. It is between these two extremes that the two worlds - of text and lived experience - are brought into dialogue, and this is where the difficult but rewarding work of interpretation takes place.

Applying this 'hermeneutic spectrum' to conservation and its relation to its doctrinal texts, the first extreme can be associated with the mechanical application of policy, as may at times be encountered within statutory systems of control; the danger here is that the users of a building - in the case of living heritage, the animating core community - become sidelined and ignored by the experts. In that case, the application of doctrinal texts often results in (metaphorical) violence towards the very thing that is keeping the heritage alive, the link between the building and the community. At the other extreme, the felt needs and narrow interests of users - and this is a very real fear when dealing with an unsympathetic developer, for example - can ride roughshod over conservation process, including the professionals representing that process, and the building that process is intended to protect. Both extremes can do incalculable harm.

All of which is to say that the way we view our doctrinal texts is crucial - and it is this that determines which parts of the 'hermeneutic spectrum' we occupy. Doctrinal texts are neither gospel truth nor an irrelevance, as the extremes would respectively imply. Rather than pushing towards one or other extreme we should make our home in the zone of dialogue in the middle, and open up a thoroughgoing engagement between (doctrinal) text and world.

${ }^{17}$ Gadamer H.-G., Truth and Method, (J. Weinsheimer \& D. G. Marshall, trans.). 2nd, rev. ed. London: Sheed and Ward, [1960] 1989, p. 306. 


\section{Phronesis}

Where we as conservation professionals place ourselves on that spectrum - and how we therefore engage with our doctrinal texts - will be determined by our understanding of the relation between theory and praxis. Gadamer addressed this question through the Artistotelian idea of phronesis, as an alternative to modern scientific method. One key aspect - key as much as for us in conservation specifically as for Gadamer's hermeneutics generally - is that knowledge is for the sake of acting in the world. For Aristotle, knowledge stems from and necessarily returns to praxis, something a universalising scientific process too easily neglects, and the form of knowledge appropriate to this action in the world is practical wisdom (in Greek phronesis, in Latin prudentia, hence 'prudence'). Aristotle's principal treatment of phronesis is in his Nicomachean Ethics, where, for example, he states,

Nor is prudence about universals only. It must also acquire knowledge of particulars, since it is concerned with action and action is about particulars. That is why in other areas also some people who lack knowledge but have experience are better in action than others who have knowledge. [...] And since prudence is concerned with action, it must possess both [the universal and the particular knowledge] or the [particular] more [than the universal] ${ }^{18}$.

On this Aristotelian view, practice and theory are in constant dialogue, each informing the other. Note the high value placed both on the particular and on practical experience, both of which are key concerns of conservation. This contrasts with the methodology of modern science, which favours the universal over the particular and which works from the assumption that once a body of theory has been established - in our case in the form of one or more doctrinal texts - then practice will follow that theory. The understanding is therefore of a unidirectional flow from theory to practice. This, of course, raises a dilemma at the heart of modern conservation. Having adopted the language of science - we term our International Committees 'Scientific', for example - we are striving for a universalism which at times will conflict with our core concern, the wellbeing of historic buildings in all their glorious and inevitable particularity.

Practical wisdom does not abandon theory; but, rather than the relation being linear, it is circular, similar to the hermeneutic circle relating part and whole. Hence, rather than application being the practical part that follows after theory has done its work, Gadamer ${ }^{19}$ insists that 'application is neither a subsequent nor merely an occasional part of the phenomenon of understanding, but codetermines it as a whole from the beginning. We cannot even understand a historic building, let alone know how to care for it, unless we keep theory and praxis in play together.

\footnotetext{
${ }^{18}$ Aristotle, Nicomachean Ethics, (T. Irwin, trans.). 2nd ed. Indianapolis, IN: Hackett, 1999, p. 92.

${ }^{19}$ Gadamer H.-G., Truth and Method, (J. Weinsheimer \& D. G. Marshall, trans.). 2nd, rev. ed. London: Sheed and Ward, [1960] 1989, p. 324.
} 


\section{The Figure of Prudentia}

In traditional Western thinking, prudence (Prudentia) was one of the four cardinal virtues (alongside justice, fortitude, and temperance). While in modern usage 'prudence' typically denotes little more than financial caution, it properly has a richer range of meaning, encompassing wisdom and the anticipation of future needs. Contemporary Roman Catholic teaching, drawing on Aristotle through Thomas Aquinas, refers to prudence evocatively as the 'auriga virtutum (the charioteer of the virtues); it guides the other virtues by setting rule and measure'20. What sort of guide then might Prudentia offer modern conservation?

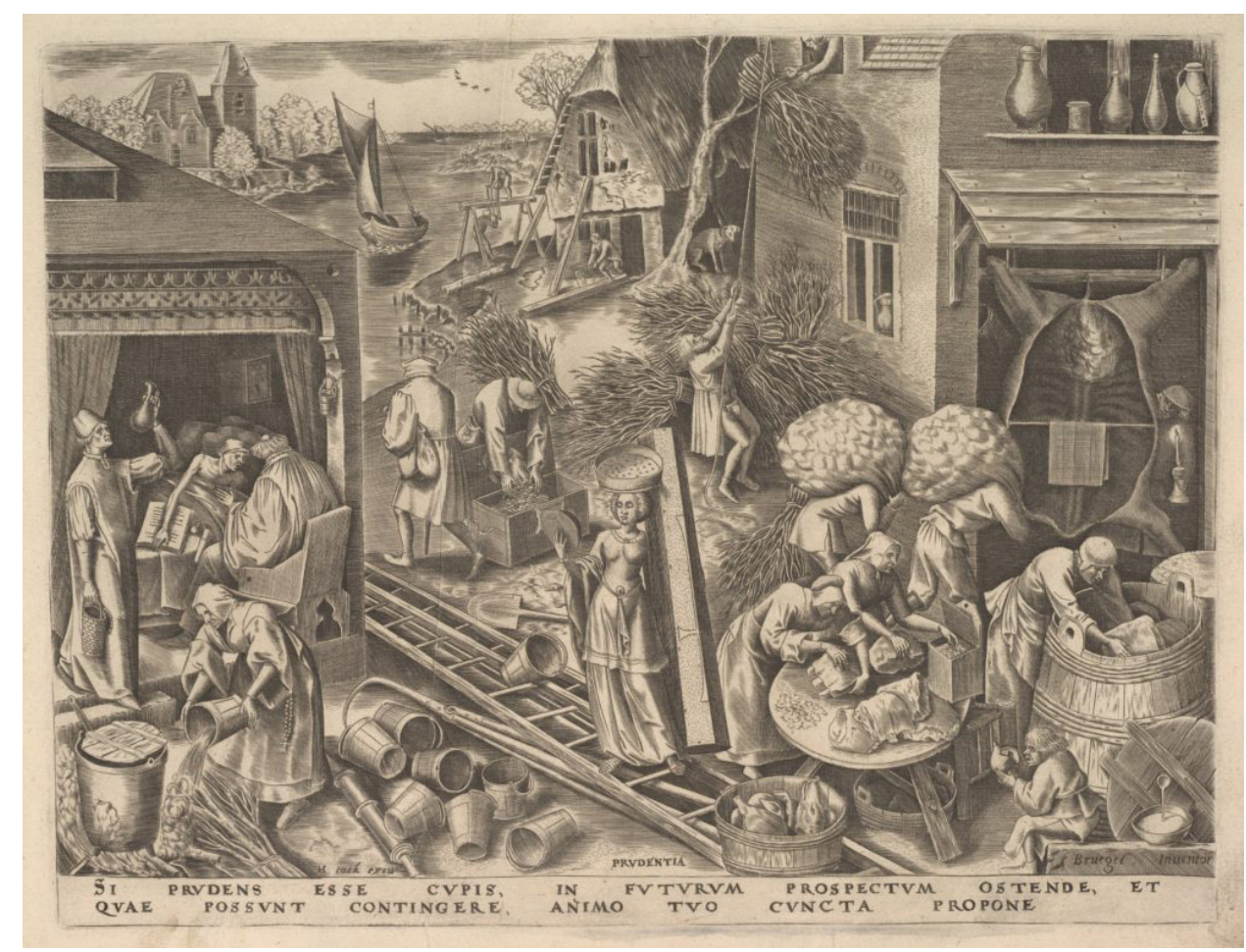

Fig. 3 Philips Galle, after Pieter Bruegel the Elder: Prudence (Prudentia) from The Virtues (1559);

Public Domain

Figure 3 shows Peter Breugel the Elder's depiction of Prudentia, from his series on the seven virtues. Every part of the image is concerned with preparedness. On the left is a man lying sick in bed, with a figure at his side who might be a notary or a priest - in either case, the point seems to be that he has his affairs in order. On the right, others are putting away provisions, salting beef, etc. Prudentia herself graces the centre of the picture, holding a coffin (a reminder of preparedness for death) and a mirror (self-knowledge). She is standing amidst and upon fire-

${ }^{20}$ Holy See, Catechism of the Catholic Church, Vatican City; Washington, D.C.: Libreria Editrice Vaticana, 2019, p. 444. 
fighting equipment - the buckets, the ladders, the thatch hook for pulling burning thatch from roofs. Perhaps the most charming of her attributes is the sieve she carries on her head - symbolic of the ability to separate good from bad.

Quite what a modern health and safety process would make of this seemingly chaotic scene need not detain us. Of greater relevance from a conservation perspective, is the industrious repair work underway to the building in the background, a direct example, avant la lettre, of William Morris's plea '...to put Protection in the place of Restoration, to stave off decay by daily care, to prop a perilous wall or mend a leaky roof...21

I suggest this rich depiction of Prudentia offers a good model for modern conservation. Prudentia represents the necessary integration between practice and theory, holding these in constant dialogue; this follows a 'practice to theory to practice' model in which each is constantly informing the other. This is much better aligned with the nature and aims of conservation, and has hugely positive consequences, for example, for the place of craft skills within conservation (directly illustrated in the image), and for the vexed debates over the relation of tangible and intangible forms of heritage more generally. If we do adopt the hermeneutic approach Prudentia exemplifies, then some principles will follow that will impact how we understand our doctrinal texts and what we expect of them. Once we place practical wisdom at the centre of our processes we will recognise that theoretical knowledge comes from and must return to praxis. We will move beyond a dualistic view of the relation between theory \& practice. And we will recognise the local human communities that animate many of our historic buildings as holders of the communal knowledge - sensus communis - which is the source of the relevant know-how on which the continuance of these buildings has always relied.

\section{Implications}

This argument has substantial implications for the ways in which we, as conservation professionals, engage with our founding documents. We must recognise:

- First, that any given doctrinal text can only ever be a particular expression of its context - which implies a constraint on the ability of these texts to establish universal principles, irrespective of the ambitions of those drafting them;

- second, that their temporality demands we engage with them hermeneutically - as texts they are themselves time-bound, and thus in need of interpretation, every bit as much as historic buildings are;

- and third, that while they are necessary and valued, such texts can at best provide conservation with a sense of direction, rather than any self-sufficient foundation.

${ }^{21}$ Morris W., The Society for the Protection of Ancient Buildings Manifesto, [1877] 2018, https://www. spab.org.uk/about-us/spab-manifesto. 


\section{Nigel Walter}

It is only when we acknowledge the limitations of our doctrinal texts that their potential can be realised. Indeed, it is precisely from the temptation to imagine our statements to be universal that many of the problems with doctrinal texts arise.

In closing, it is perhaps helpful to return to those three criteria noted above from the 1984 ICOMOS Procedure For The Adoption Of A Doctrinal Text - affirmation, interpretation and action. First, there certainly are truths to be affirmed, and doctrinal texts are the natural place to assert them. However, we should not expect those asserted truths to fit together seamlessly as if they were precision-made components that can be assembled into a faultless mechanism. At an individual level our texts will always lack that precision; and despite the efforts to assert order between them as discussed above, there is little evidence of overall design. They remain a collection, rather than a corpus.

Second, doctrinal texts of all types can certainly help with the interpretation of the specific situations faced by conservation professionals in their work, but they themselves must also submit to an ongoing process of interpretation. And third, doctrinal texts remain resolutely oriented towards action. And here's the rub. These texts guide our praxis and therefore have a degree of agency that results in real world impacts. Get these documents wrong, and they can do significant harm; get them right, and they can do a great deal of good in safeguarding our heritage for future generations. And the best hope of getting them right is for theory and praxis to remain in dialogue, as what I suggest should be conservation's cardinal virtue, Prudentia, insists.

Which brings us back to the second resolution of the Athens Charter. We must approach our doctrinal texts as themselves a restoration and conservation project, which like any other should be 'subjected to knowledgeable criticism to prevent mistakes which will cause loss of character and historical values to the structures'. In this way, we are adopting a hermeneutic approach; therein lies the best hope for the continued relevance and usefulness of our doctrinal texts, provided that that knowledgeable criticism remains firmly rooted in praxis. 


\section{Bibliography}

A Cultural Heritage Manifesto, ICOMOS-UK 2015, http://www.icomos-uk.org/uploads/sidebar/ PDF/A\%20Cultural\%20Heritage\%20Manifesto.pdf.

Annual Report 2009, Volume 1, Paris: ICOMOS 2013, https://www.icomos.org/images/ DOCUMENTS/Secretariat/Annual_Reports/AR2009_Vol1complet_finalweb_20130618.pdf.

Aristotle, Nicomachean Ethics, (T. Irwin, trans.). 2nd ed. Indianapolis, IN: Hackett, 1999.

Convention Concerning the Protection of the World Cultural and Natural Heritage, UNESCO 1972, http://whc.unesco.org/archive/convention-en.pdf.

Convention for the Safeguarding of the Intangible Cultural Heritage, UNESCO 2003, https://ich. unesco.org/en/convention.

Daniels S., Cosgrove D.E., Introduction: Iconography and Landscape, [in:] The Iconography of Landscape: Essays on the Symbolic Representation, Design, and Use of Past Environments, Cambridge and New York: Cambridge University Press, 1988.

Gadamer H.-G., On the Scope and Function of Hermeneutical Reflection, (D. E. Linge, trans.), [in:] Philosophical Hermeneutics, Berkeley and Los Angeles, CA: University of California Press. 1976.

Gadamer H.-G., Truth and Method, (J. Weinsheimer \& D. G. Marshall, trans.). 2nd, rev. ed., London: Sheed and Ward, [1960] 1989.

Grondin J., Introduction to Philosophical Hermeneutics, New Haven, CT: Yale University Press, 1994. Holy See, Catechism of the Catholic Church,Vatican City; Washington, D.C.: Libreria Editrice Vaticana, 2019.

International Charter on the Conservation and Restoration of Monuments and Sites, Paris: ICOMOS, 1964.

Resolutions of the 16th General Assembl, Paris: ICOMOS 2008, https://www.icomos.org/ quebec2008/resolutions/pdf/GA16_Resolutions_final_EN.pdf.

Lowenthal D., The Past Is a Foreign Country - Revisited, Cambridge: Cambridge University Press, 2015.

Morris W., The Society for the Protection of Ancient Buildings Manifesto, [1877] 2018, https:// www.spab.org.uk/about-us/spab-manifesto.

Szmygin B., Formal Analysis of Doctrinal Texts in Heritage Protection, [in:] M. S. Falser, W. Lipp, A. Tomaszewski (eds.) Conservation and Preservation: Interactions between Theory and Practice: In Memoriam Alois Riegl (1858-1905), Firenze: Edizioni Polistampa, 2010.

The Burra Charter: The Australia ICOMOS Charter for Places of Cultural Significance, 2013. Burwood, Australia: Australia ICOMOS, 2013.

The Nara Document on Authenticity, ICOMOS 1994, https://www.icomos.org/charters/nara-e.pdf. Walter N., Narrative Theory in Conservation: Change and Living Buildings, Abingdon and New York: Routledgel, 2020. 